\title{
A Knotworking Guideline for Building Projects: Bridging the Gap between Participants
}

\author{
Mai Brink Rasmussen*, Anne Nørkjær Gade**, Rasmus Lund Jensen*** \\ *Department of Civil Engineering, Aalborg University, Denmark \\ Email: mbr@civil.aau.dk \\ **Department of Energy and Environment, University College of Northern Denmark, and Department of Civil \\ Engineering, Aalborg University, Denmark \\ Email:anni@ucn.dk \\ ***Department of Civil Engineering, Aalborg University, Denmark \\ Email:rlj@civil.aau.dk
}

\begin{abstract}
The high level of complexity in today's building design requires a high level of multidisciplinary collaboration, which historically is uncommon in the Architecture, Construction and Engineering (AEC) sector. While the AEC sector accepts the requirement of collaboration, lack of knowledge on how to collaborate occurs. The Finnish method, Knotworking AEC, emphasises both collaboration and structure of building projects, which accommodates the lack of collaboration in the practices of the AEC sector. However, the recent development of Knotworking AEC implies a lack of written articles on Knotworking AEC, why three experiments were conducted to gain knowledge about how Knotworking is utilised in practice. Through a practice theoretical perspective, data was collected from existing literature and participant observation of two experiments. Subsequently, the practices and contradictions of the three experiments were analysed by practice theoretical methods. The result of this research is a Knotworking Guideline for Building Projects indicating both the phases, the participants and the tasks of each phase. The contribution of the result lies in the conduction of a Knotworking session from both a practical and research perspective to, respectively, enrich the AEC sector and the concept of Knotworking AEC.
\end{abstract}

Keywords: AEC sector, Building management, Co-configuration, Collaboration, Design process

\section{INTRODUCTION}

Worldwide, building projects are complex, which is emphasised in major iconic buildings such as Sydney Opera House in Australia, La Sagrada de Familia in Spain and Burj Al Arabin in the United Arab Emirates. An increase of requirements in the building industry such as legislations, sustainability and new technologies adds to this complexity [1], [2]. Further, the requirements resonance an increase of the amount of involved experts in the building design process caused by the body of knowledge interconnected to the specific discipline [3]. However, the involvement of multiple disciplines does not automatically conduct building projects fulfilling all requirements. A general statement of the Architecture, Engineer and Construction (AEC) sector being prone to numerous of faults and deficiencies of the specific building projects and related time and cost overruns illuminates this statement [4]-[6]. For this reason, multidisciplinary collaboration among the participants is required to design holistic buildings fulfilling the increase of complexity within the AEC sector. Echoing this claim, the AEC sector is no longer questioning if collaboration is imperative, but rather questions how to conduct collaboration [3]. This research aims to bridge the gap between the multiple participants of a building project.

\subsection{Silo-approach}

The traditional method of collaboration in the AEC sector is often described as the Siloapproach [3], [7]. The Silo-approach divides the professions into separate silos and tasks as a guild structure based on the specific craft productions and commercial practices [3] (Fig. 1).

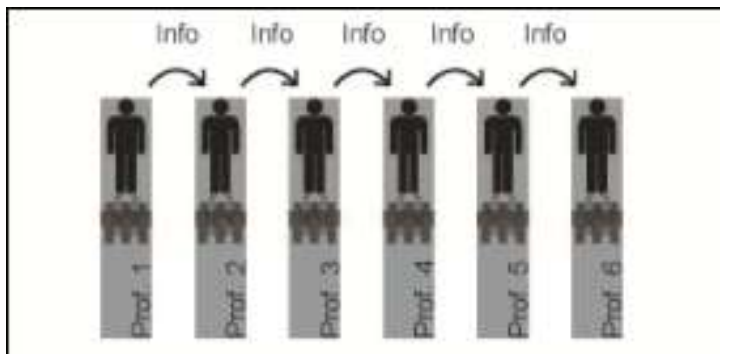

Fig. 1: Silo-approach and 'over the wall' syndrome. Each silo represents a profession with a leader of the profession and related employees. The leaders are the once corresponding with each other. 
The communication among the silos is often referred to as the 'over the wall' syndrome illustrating the fragmentation of information delivery among the participants of a project with lack of communication and iterative processes (Fig. 1). This lack often results in costly changes and loss of information [8]. According to Zhuang et al. [7], the inefficiencies of a building project occur whenever there is a hand-off from one silo to another. The examples of building projects implementing the Silo-approach is many, such as a University building with a time overrun of three years according to original schedule due to lack of both collaboration, management and information delivery among the participants [9]. This claim is further consolidated by previous studies indicating that experts, in general, commit to their own tasks and consequently are uninterested in the overall design [10]. The aim of the Silo-approach is to enhance the professions, and their practical tasks, based on the beliefs of efficiency by people working with their talent.

\subsection{Collaboration}

In recent years, the number of participants involved in the design process has increased by involving the end-user. Involving the end-users has gained popularity based on the benefits of developing a product useful for and fulfilling the requirements of the users [11]. Traditionally, through the Silo-approach, the involvement of the end-user is mediated through textual requirements prior to the design process and through verification of the project at the end of a phase [12]. Based on the fact that the AEC sector requires collaboration [3], new concepts of involving the end-user are developed. Some of these concepts are co-design, developing a product collaboratively in the making [13], [14], co-marketing, branding a product collaboratively [15], co-creation, developing a product collaboratively for the user to change subsequently [16], [17] and co-configuration, continuously developing a product for all the participants being the receiver of the product [18], [19]. These concepts involve the end-user in slightly different ways (Fig. 2), however, the common denominator is the mediation of collaborative creation of knowledge [20].

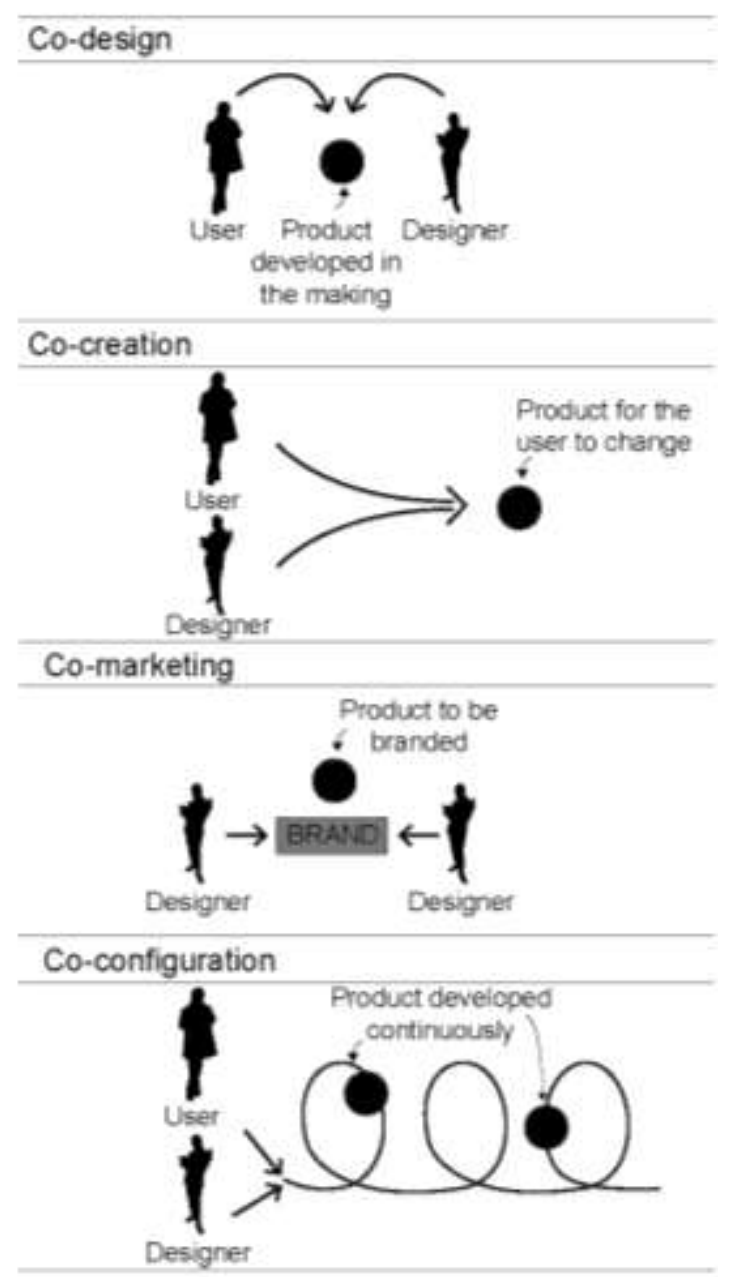

Fig. 2: Illustrations of an extraction of methods involving the end-user.

While the concepts are focused on collaboration, they lack managing a project and involve the tasks of a project.

\subsection{Knotworking for building projects}

The method of Knotworking for building projects (Knotworking AEC from now on in this paper) is an approach accommodating both collaborations among participants and organisation of the themes to be implemented in the project [21], [22]. As a first, Knotworking AEC was adopted to the Finnish AEC sector in a development programme $2012-2015$ by a collaborative team of researchers, building owners and executers as an approach for collaboration [21]. This Knotworking session is further in this paper referred to as the first experiment of this paper. Theoretically, Knotworking as a concept was developed as an object-oriented approach for collaborative learning [23] based on the theoretical background of culturalhistorical activity theory (Activity theory from now on in this paper). Activity theory is an objectoriented approach founded in the Soviet Union in the 
1920 s and 1930s by a group of cultural psychologists [24], [25]. The general idea of Knotworking requires a subject, an object and related tools, rules, division of labour and community [21]. Previously, Knotworking AEC has been validated through examples such as in the design of a school community centre in Finland in 2013 [26] and Skagen lifeboat station in Denmark in 2014 [27]. Contextually, Knotworking AEC can be related to the American Big Room according to colocation, invented to improve collaboration among multiple participants with various backgrounds [28], [29]. The advantages of the Big Room are spontaneous collaboration among the participants to solve a certain task of the project [30], [31], time and cost efficiency and high quality of the outcome [28], [29]. Based on these advantages, multiple large building projects, especially in America, have implemented the structure of Big Room. The resources of the project or the company determines the appropriation of Big Room for the specific project, requiring the capacity to allocate all participants on the same project for months. Small projects or companies unable to allocate one or multiple employees at one project continuously are inappropriate for Big Room [29]. Thus, Knotworking AEC supports small companies, collecting all participants for two to three days for collaboration on the specific project with intervals of three to four weeks according to the complexity of the project [26].

Further, in this study it is suggested, that Knotworking structures a project into the themes of the project (Fig. 3) such as accessibility, daylight, materials and sustainability. Fig. 3 illustrates the themes of a project by black dots. When a theme is connected to several other themes, the theme becomes a knot, as illustrated in step 2 by the orange dots (Fig. 3). Moreover, the connection to other themes emphasises the multidisciplinary interest in the knot, because the themes are related to disciplines. By having multiple themes connected to a knot, multiple disciplines are automatically connected to the knot. By collaboratively defining the knots prior to the Knotworking session, the knots are structured to be collaboratively solved at the Knotworking sessions, as illustrated in step 3. When solving a knot, related themes are simultaneously solved unconsciously by multiple professions with interest in the specific knot (Fig. 3). However, Knotworking AEC is based on the concept of Knotworking emphasising that the centre (the knot) is changeable according to the context, why the solving of one knot potentially spontaneously develops a new knot not pre-defined, but crucial to solve [23], [32].
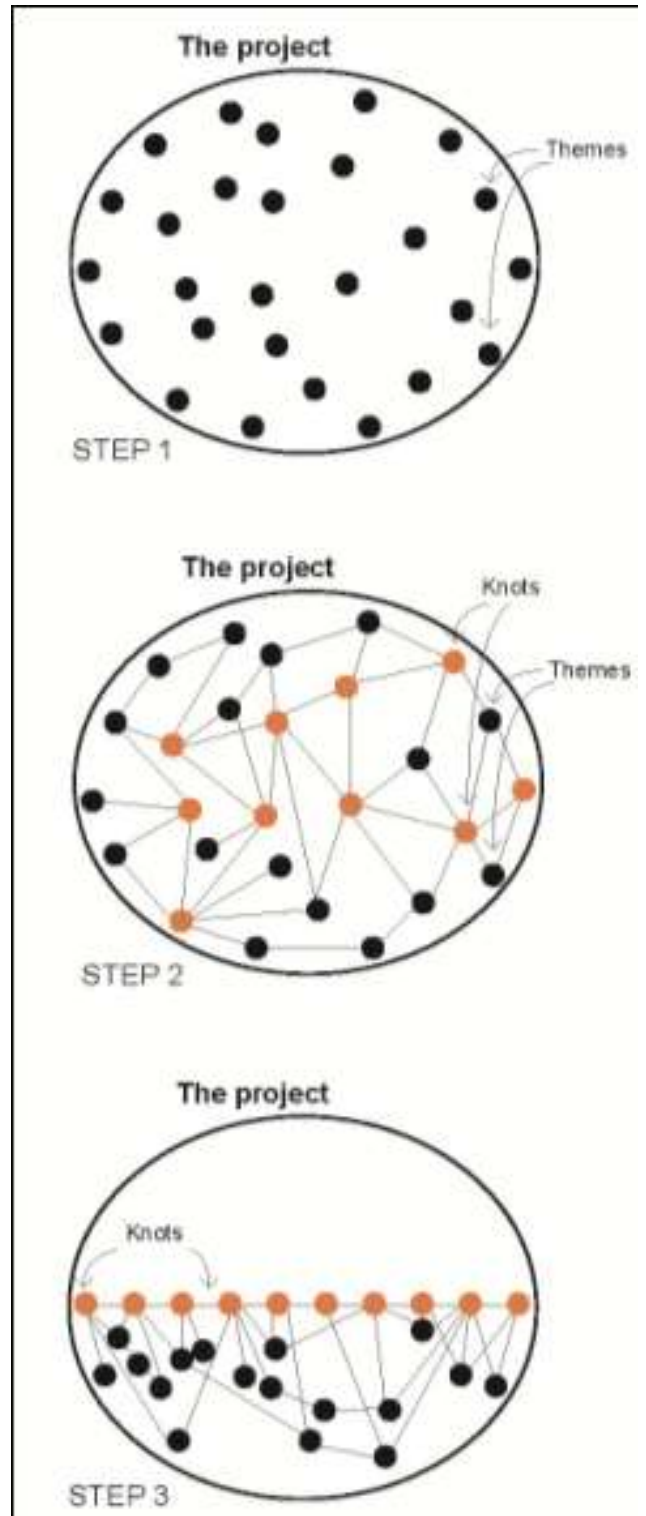

Fig. 3: Three steps of Knotworking.

Contrary the Silo-approach dividing each profession into separate silos and working hierarchically, Knotworking AEC embrace collaboration by collecting all participants (Fig. 4). The collaboration of Knotworking is often carried out in two phases by firstly collecting all participants at a table to discuss the project, and secondly working disciplinary or collaboratively among few professions (Fig. 4). Through collaboration, the participants create a human network and a network of knowledge which is stable compared to Knotworking being changeable [32]. 


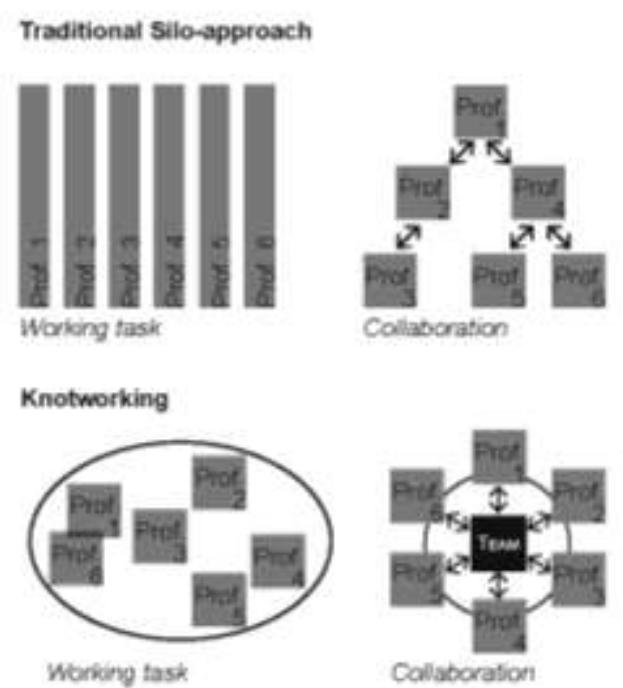

Fig. 4: Comparison of traditional Silo-approach and Knotworking. The diagrams indicate numerous of involved professions, the approach of working task and form of collaboration.

The advantages of Knotworking are the potential of the participants having simultaneous projects while gaining the advantages of the Big Room method, such as quick response to a problem, time and cost efficiency and high quality of the outcome. According to Kerosuo [21], projects adopting Knotworking compress the process from two weeks to two days containing the same level of quality. Moreover, "it speeded up the decisionmaking and enabled the different parties to commit themselves to the achievement of a common goal" [21, p. 207]. Additionally, the method acknowledged the test of solutions developing potential results [26].

Despite the fact that Knotworking AEC has confusing similarities with workshops, the significant differences are that Knotworking AEC is a method useable in a workshop. The Knotworking session can be described as a workshop, but the activities of a Knotworking session is the essence of Knotworking AEC. In the Knotworking sessions, all participants continuously and collaboratively develop knots during the Knotworking session as an iterative design process. Knotworking AEC is organised by collaboration of sequences of collaboration among the participants and individual work, whereas workshops has the freedom of various collaboration approaches.

Knotworking is a new idea that is experimented with different kinds of AEC projects, but there are not yet many publications available of them, why Knotworking AEC is an open idea requiring localisation in multiple projects. As an example, the visualisation of how to conduct a Knotworking session requires development for implementation in various building projects. Lassila
[33], a Finnish master thesis student in architecture at Tampere University of Technology, has developed a concept of Recipe method based on Knotworking, BIM and Lean thinking, to improve the design process of a building project through a practical tool for design management [33]. The Recipe is an iterative process pointing out the ingredients of a building project and the mixing order of an improved design process [33]. The Recipe is focused on sustainable buildings and the ingredients for a design process related to that.

According to various research [34]-[37] and practical architects [38], iterations are essential for the creativity, why a visualisation, e.g. mediated as a guideline, requires space for iterations within each phase. Of this reason, the research question of this research is "What does a Knotworking AEC guideline, framing collaboration and the related tasks, contain, for the participants to focus on their discipline and their strengths?" Based on previous literature of Knotworking and three experiments, the result of the study is a general Knotworking Guideline for Building Projects performing a Knotworking session and a related brief description of the specific tasks of the guideline in the AEC sector. The Guideline accompanies planning a Knotworking session. Further, it is discussed how the Guideline differs from the Knotworking Recipe, how collaboration is related to the Guideline and the applicability in similar industries. Lastly, a conclusion summarises the key aspects of the findings.

\section{MATERIALS AND METHODS 2.1. Materials}

To reach the objectives, the data of this research is based on three experiments; A Finnish Knotworking session of a school project documented in the previous literature of Knotworking AEC, and two experiments conducted in Denmark on a furnishing session and an extension of a primary school.

\subsubsection{Three experiments}

The idea of Knotworking AEC is primarily based on experiments caused by a lack of published work due to the recent development of Knotworking AEC. The Finnish experiment used in this research covered collaboration among researchers, designers, construction professionals, cost analysts, building information model experts, structural engineers and contractors' representatives with the objective of designing a school community centre in Central Finland [21], [30], [39]. Based on unstructured interviews with one of the researchers being a part of the Knotworking sessions, the data of this experiment were collected. The participants of the Knotworking session were divided into two groups 
aiming to design a school community centre. The variety of the two groups were mediated through the tasks of the groups; One group was designing an extension to a historically valuable building, while the other group was designing a freestanding building. The duration of the Knotworking session was two days covering eight hours in total. Roughly, the eight hours were equally divided into independent and collaborative work of the disciplines of the participants in the groups.

The results of this research were efficiency according to six design proposals within eight hours, which originally would take a couple of weeks to produce. Moreover, the participants achieved a common goal for the project emphasised by the productivity of the project. The two groups worked differently: One group enhanced the preparation of the design process, while the other group skipped the preparation for the Knotworking session. The group skipping the preparation spend two hours at the Knotworking session for preparation prior to initiating their design, while the group prepared for the Knotworking session initiated the design half an hour into the Knotworking session. This indicates the importance of preparation for all participants. Further, in this paper, this experiment is referred to as the school project.

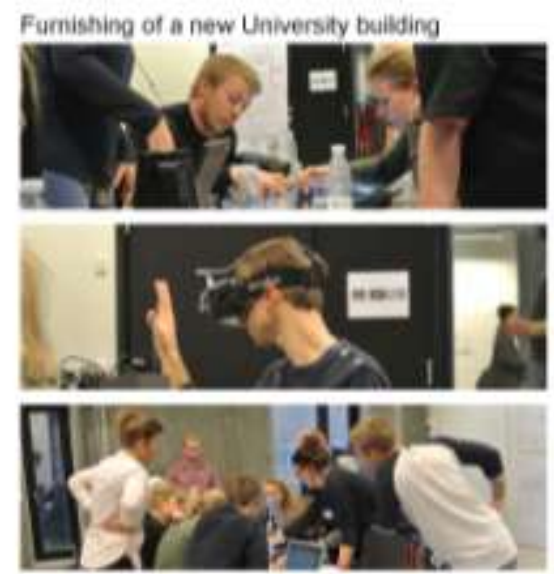

Fig. 5: Pictures from the second experiment. The pictures visualise the furnishing session.

The second experiment was developed based on the Knotworking AEC approach of the school project. The experiment conducted a furnishing design process for a new University building (Fig. 5) having the duration of one and a half day with two weeks in between; Day 1, the 24 November 2015, from 8:00 AM to 3:15 PM and day 2 , the 8 December 2015, from 8.00 AM to noon. The two weeks in between allocated time for reflection on the furnishing design proposals designed at the first workshop. The aim of the first Knotworking session was to furnish the non-laboratory spaces covering 5500 square meters, while the second Knotworking session aimed to refine the furnished plans from the first Knotworking session. The design workshops involved 20 actors representing users of the specific building such as students, staff, janitors and cleaning staff along with internal interior designers at the University and furniture manufacturers. For both workshops, the 20 actors were divided into two groups - 'Group students' and 'Group staff' - involving at least one participant from each discipline. The aim of the groups was to furnish specific rooms predefined as knots by the facilitator. The facilitator managed the furnishing design process by being an objective manager focusing on the progression of the participant's work and not on the content. The primary tools allocated for furnishing the spaces were a touchscreen and VR glasses. The touchscreen mediated the movements of the $3 \mathrm{D}$ furniture representing the future furniture of the building within a BIM model of the building. The VR glasses mediated the spaciousness of the predefined rooms for the participants to understand the dimensions spatially (Fig. 5). 30 minutes were spent on furnishing the floor plans for each predefined room, 15 minutes for evaluating the furnished floor plans followed by 20 minutes to present and discuss the evaluated furnished floor plans for the opponent group. To evaluate the Knotwokring phases, post-its for comments were handed out at the beginning and at the end of each day.

The main results of the day were ownership of the building, efficiency of the production of proposals and furnishing according to the requirements of the participants. The collaborative development of the furnishing design enhanced the identification of the demands of the participants by e.g. the students questioning why soft materials could not pad the student chairs. The cleaning staff argued by the difficulties of maintaining the soft materials even though the cleaning staff understood the proposal of the student. The discussion was followed by the furniture manufacturer proposing other cleaning friendly materials than the traditional materials, resulting in student chairs with soft materials in the lecture rooms and hard chairs in the food areas caused by the cleaning. This discussion was a successively implemented caused by the Knotworking session focusing on furnishing the lecture room - a shared object to reach. The comments of the cleaning staff subsequently to the Knotworking session emphasised that this session with the involvement of the cleaning staff was a revolution of furnishing at the University. A janitor supported this commet, by indicating that he had been waiting for this collaboration and involvement for 30 years. They finished the session by saying thank you very much to the researchers, and that it 
had been fascinating and exciting to be a part of the session. By being a part of the session, the participants moreover gained ownership of the furnishing, which was observed in between the two sessions. The cleaning staff involved in the Knotworking session proudly showed the results to her colleagues for subsequently to receive their comments and enjoyment of being asked in the process. Moreover, the scientific staff of the department indicated that the furnishing had become more individual while the furnishing style was mutual throughout the building. The mutuality enhanced the collaboration and holistic approach to the building compared to the previous furniture being a mix of many ages and design styles. In relation to the furnishing, a staff member indicated, that she believed, that it would be a great building, pointing out that by being a part of the furnishing, she gained ownership of the entire building and not only the furnishing, which was fruitful for the transformation of moving into the new facilities.

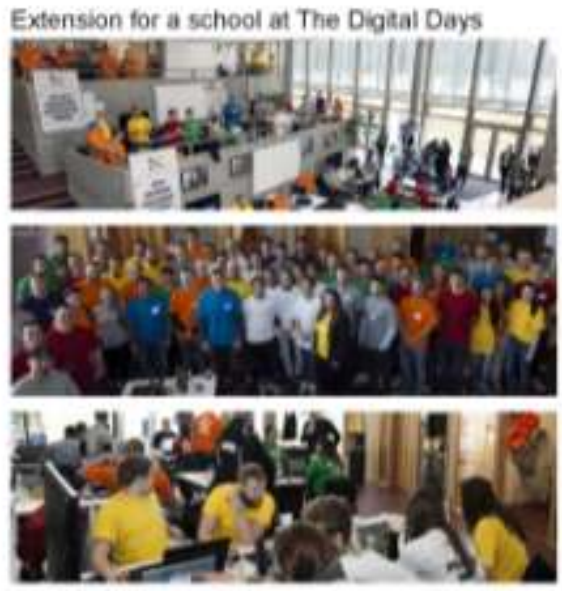

Fig. 6: Pictures from the third experiments. The pictures visualise the Digital Days.

The third experiment was four student projects developing a renovation of a section of a primary school (Fig. 6). The session was called the Digital Days lasting three days, 13-15 April 2016. The session was arranged as a Big Room session with spots of Knotworking according to collaboration method and pre-defined knots. The purpose of this experiment was dualistic; Firstly as an experiment of implementing guiding sheets to improve the implementation of the Knotworking method without the researcher being the facilitator, and secondly as a learning experience of collaboration and working with digital tools in multidisciplinary teams aiming to renovate a section of an existing school. The experiment involved 72 participants grouped into four teams covering students studying various professions. Based on their profession, the students were dressed in coloured $\mathrm{T}$-shirts indicating the specific professions (Fig. 6). The four teams were situated in a three level open space allocating four spaces - one for each team. From a Knotworking perspective, the participants were introduced to four sheets to be fulfilled for the students to pass the workshop. The first sheet was a gross-net-list of potential themes to investigate within their project. The groups were forced to pre-define their own knots prior to the Knotworking session, to gain a mutual object of the project at the initiation of the workshop. The second sheet aimed to streamline the fortified Knotworking meetings. The sheet was arranged by indicating the pre-defined knot and the new knot developed through the Knotworking meeting. Thirdly, a subject-oriented BygSoL [40] meeting sheet aimed to improve collaboration among the participants by noting the single participant, the challenges of this participant and the participant helping the first participant to solve the challenge. The fourth and last sheet was an evaluation sheet to illuminate the most important and most difficult aspects of implementing Knotworking.

One of the results of the third experiment was the efficiency of the initiation of the project session. At the first day, the students knew what to do, based on the gross-net-lists discussed at the preparation session two weeks prior to the project session. The gross-net-list was primarily utilised in the initiation of the project, where the rest of the project was developed upon new knots. The Knotworking meeting indicated the difficulties of collecting all participants at one session caused by the fact that the working methods of the participants differed. By fortifying the meetings, the participants were forced to meet which resulted in a structure of the project. A student commented that it was nice with a structure of both collaboration and the themes of the project when chaos appeared, for the participants to agree upon the next task.

\subsubsection{Comparisons of the experiment and the Finnish Knotworking session}

The varieties of the three experiments are emphasised in the following comparison. The areas indicate the basis of comparison while the three columns indicate each Knotworking session. The three Knotworking sessions are similar according to Quality, Feedback and Timetable, which in general indicate a compressed schedule despite a high level of quality and positive feedback. The major differences are Amount of groups, Work of the facilitator, Homework and Involved actors (Fig. 7). 

ISSN : 2248-9622, Vol. 7, Issue 6, (Part -4) June 2017, pp.24-40

\begin{tabular}{|c|c|c|c|}
\hline \multicolumn{4}{|c|}{ COMPARISON OF THREE EXPERIMENTS } \\
\hline Aveas & Schod Proect & Furnshing Design & Digtal Days \\
\hline $\begin{array}{l}\text { Amount of } \\
\text { participants }\end{array}$ & 1 group & 2 groups $-2 \times 11$ actors & 4 groups $-4 \times 18$ actors \\
\hline Preparation & $\begin{array}{l}\text { Met ahead of the session and } \\
\text { discussed the purpose and } \\
\text { timetable }\end{array}$ & $\begin{array}{l}\text { Facilitator had pre-defined the } \\
\text { purpose and the timetable }\end{array}$ & $\begin{array}{l}\text { Met ahead of the session and } \\
\text { discussed the purpose and } \\
\text { timetable }\end{array}$ \\
\hline Duration & 2 days & 2 days & 3 day 5 \\
\hline Homework & $\begin{array}{l}\text { All participating actors present- } \\
\text { ed their approach to the pro- } \\
\text { ject. Homework for the actors }\end{array}$ & $\begin{array}{l}\text { Facilitator presented the } \\
\text { approach for the project. No } \\
\text { homework for the actors }\end{array}$ & $\begin{array}{l}\text { Homework for the actors with } \\
\text { the installation of agreed soft- } \\
\text { ware as one of the tasks }\end{array}$ \\
\hline $\begin{array}{l}\text { Working } \\
\text { procedure }\end{array}$ & 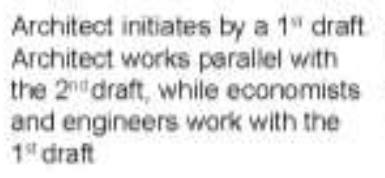 & $\begin{array}{l}\text { All actors are working from the } \\
\text { beginning of the Knotworking } \\
\text { session and collaborates con. } \\
\text { stantly within each group }\end{array}$ & $\begin{array}{l}\text { Architect initiates by a } 1^{\prime \prime} \text { draft. } \\
\text { Architect works parailel with } \\
\text { the } 2^{\prime \prime} \text { draft, while economists } \\
\text { and engineers work with the } \\
1^{\text {"d draft }}\end{array}$ \\
\hline Presentation & $\begin{array}{l}\text { Feedback presentations } \\
\text { among the professions }\end{array}$ & $\begin{array}{l}\text { Feedback presentation among } \\
\text { the } 2 \text { groups }\end{array}$ & $\begin{array}{l}\text { Feedback presentations } \\
\text { among the professions }\end{array}$ \\
\hline $\begin{array}{l}\text { Involved } \\
\text { actors }\end{array}$ & $\begin{array}{l}\text { Specialists presents for the us- } \\
\text { ers and the building owner at } \\
\text { the end of the } 2^{\text {nd day }} \text { Low par- } \\
\text { ticipation by users and building } \\
\text { owner during the process }\end{array}$ & $\begin{array}{l}\text { The end-users are a part of } \\
\text { the Knotworking session. The } \\
\text { end-users decides the furnish- } \\
\text { ing principles at the } 2^{\text {" d day }}\end{array}$ & $\begin{array}{l}\text { Specialists presents for the } \\
\text { users and the building owner } \\
\text { at the end of the } 2^{\text {nin day. Users }} \\
\text { a part of the groups during the } \\
\text { process }\end{array}$ \\
\hline Quality & $\begin{array}{l}\text { Short time, but the quality of } \\
\text { the work was high }\end{array}$ & $\begin{array}{l}\text { Short time, but the quality of } \\
\text { the work was high }\end{array}$ & $\begin{array}{l}\text { Short time, but the quality of } \\
\text { the work was high }\end{array}$ \\
\hline Leader & $\begin{array}{l}\text { One leader in the group who } \\
\text { atso desigred the building }\end{array}$ & $\begin{array}{l}\text { Main facilitator and } 1 \text { leader in } \\
\text { each group }\end{array}$ & $\begin{array}{l}\text { One leader in the groups who } \\
\text { also calculated the building } \\
\text { budget }\end{array}$ \\
\hline Feedback & $\begin{array}{l}\text { Knotworking makes it possible } \\
\text { to get direct feedback }\end{array}$ & $\begin{array}{l}\text { Knotworking makes it possible } \\
\text { to get direct feedback }\end{array}$ & $\begin{array}{l}\text { Knotworking makes it possible } \\
\text { to get direct feedback }\end{array}$ \\
\hline Timetable & $\begin{array}{l}\text { Time pressure } \\
\text { Perosid } 2015 \text { ) }\end{array}$ & Time pressure & Time pressure \\
\hline
\end{tabular}

Fig. 7: A comparison of three experiments with Knotworking. One experiment was conducted in Finland, while the two others were carried out in Denmark.

\subsection{Methods}

The theoretical perspective of this research is practice theory, caused by the aim of improving future design processes using the method of Knotworking AEC. Practice theory focuses on the practice in between investigating how an individual reacts and how a system is, which in general relies on the de-centring of the participant to an attention towards the collective organisation of the practice [41], [42]. In the 1970s, practice theory emerged as a theoretical elaboration between post-structuralism and pragmatism, based on phenomenology and a Wittgensteinian perspective [41], [43]. While it, in general, is claimed that there is no unified practice approach, there is a network of theoretical approaches connected by historically and conceptual similarities [44], [45]. Some of these theoretical approaches are activity theory (Vygotsky, Engeström), praxeology (Bourdieu, Giddens), ethnomethodology (Garfinkel), mediate discourse analysis (Scollon) and Wittgenstein/Heidegger tradition (Schatzki, Shove, Warde, Reckwitz) [41], [46]. Fundamentally, practice theory focuses on the doings, habits, routines, practical consciousness and collectivism of a practice [47]. By focusing on the doings and the habits of the participants of the experiments, the potential lacks of implementation of Knotworking in the experiments are emphasised to improve the application and develop the results of this paper. The holistic approach to the practice having the human in focus is essential for developing a tool to support the improvement of design processes in the AEC sector. Practice theory is for this reason used as the theoretical framework to investigate the practices of the experiments. Further, analytical methods related to this theoretical 
framework are selected to complete the analysis for developing the result of this research.

\subsubsection{Unstructured interview}

Unstructured interviews aim at understanding the flow of the world by tolerating a significant amount of data from the interviewee [48]. Subsequently, the data flow is analysed to make the data informative. The discipline of unstructured interviews requires self-discipline and a bright memory of the interviewer why the discipline occurs as difficult [48]. The data flow of the interviewee is large caused by the fact that the conversation often deviates from the intended topic based on both interest and mood of the interviewee [48]. The significance of unstructured interview is the lack of preparation prior to the interview because the interviewer interacts with the interviewee in the field and often the unstructured interview is spontaneous. For the data collection of experiment one, unstructured interviews were performed over lunch, at conferences and subsequently to organised meetings. The unstructured interviews included researchers being involved in the Knotworking sessions of experiment one and Skagen lifeboat station [27]. Subsequently to the unstructured interviews, the data were collected by notes supported by existing literature.

\subsubsection{Participant observation}

Participant observation is one of the purest methods of social science, caused by the observer being a part of the context of the practice [49]. Contrary questionnaire surveys and interviews, participant observation enrich the data collection through observing what happens [42], which supports the theoretical framework of practice theory. Bodily and mentally, the researcher absorbs the historical background of the observed practice for further analysis. However, the participant observer is inhibited by the personal culturalhistorical background, why objectified observations of the practice are impossible, because of a dualistic approach to both the epistemic practice and the personal practice of what concerns the researcher personally [45]. Participant observation has in this research been utilised for data collection of the second and the third experiment.

In the second experiment, one of the researchers acted as the facilitator of the Knotworking session to adopt the context of the practices to observe. The focus of the researcher was dualistic; on the one hand, to ensure smooth enrollment of the Knotworking method for the enjoyment of the participants and production of furnishing plans. On the other hand, to focus on the epistemic practice of collecting data for analysing how the practice of the Knotworking session appeared, followed by pros and cons of implementing both Knotworking and end-users in the Knotworking session.

In the third experiment, one of the researchers was a participant observer influencing the practice of the students prior to the three days by implementing a gross-net-list of potential themes of the future project. The purpose of the gross-net-list was to generate a mutual object of the project. Throughout the three days of the experiment, the researcher observed the working methods and collaboration of the students and supervised them to fulfil the mandatory Knotworking meetings. The Knotworking meetings were mandatory to investigate if Knotworking was beneficial for the collaboration by fortification and if the facilitator was not the developer of the Knotworking session, as was the case of the second experiment.

\subsubsection{A palette of zooming in}

Based on the practice-theoretical approach, the theory-method package called 'A palette for zooming in', developed by Nicolini [45], is applied for analysing the practices of the experiments. The theory-method package is developed for "zooming in on the accomplishments of practice; zooming out to discern their relationships in space and time" [45, p. 219]. Through eight focus areas and related sensitising research questions, the theory-method package becomes a programmed eclecticism caused by the outlines of Nicolini stating "that to study practice empirically we are better served by a strategy based on deliberately switching between theoretical sensitivities" [45, p. 213]. By applying 'A palette of zooming in' on the practices of the experiments, the practices are analysed from multiple perspectives to investigate the complexity of the world without simplifying the complexity. To maintain the focus on the practice, the practice is the smallest unit of the analysis, why the focus is the connections among the practices contrary the details of the specific practice [42].

The analysis was conducted respectively one and one and a half year subsequently to the execution of the experiments. The purpose of the postponement of analysis was the enrichment of the time span conducting a mental distance to the data collected by participant observation. Each experiment was categorised as one separate practice, as the smallest unit to analyse. The theory-method package was executed singularly on the three experiments even though the data of the first experiment was gained from existing articles and casual conversations with the researcher being a part of the first experiment. The theory-method package was conducted sporadically, initiated by the physical objects and tools of the practices to be followed by the psychological aspects of the practice. Caused by 
the length of the analysis, various forgotten anecdotes appeared through the analysis, which further was significant for the results of this paper.

\subsubsection{Development of result based on data}

The result of this data collection is developed based on an iterative process to concentrate the focus of this research. The iterative process contained five loops of various experiments prior to determine the focus of this research (Fig. 8). Firstly, a case of a University building for Department of Civil Engineering at Aalborg University was followed to conduct data to be analysed [9]. Based on mind maps, the case enlightened 'collaboration' as a key problem in practice. Through unstructured interviews with researchers involved in the first experiment of this research, the benefits of Knotworking as a method for 'collaboration' and 'progression' of a building design process was emphasised. The third loop of iteration contained a Skagen lifeboat station in Denmark using Knotworking as a method for 'collaboration' and 'progression' of the building project [27]. Through reports and unstructured interviews of facilitators of Skagen lifeboat station, the 'themes' of a building project and the 'participants' involved was enlightened. Based on the previous loops and a narrowing of the field of research, the second experiment of this research was conducted. Mind maps and participant observations emphasised the 'preparation tasks' of a Knotworking session and the 'participants' involved [50]. The final loop of iteration was the third experiment focusing on the 'themes' of building projects and the 'organisation of conducting' a Knotworking session without supervision of the developer of Knotworking AEC.

The concentration of the iterative process conducted a requirement of a guideline for 'progression' of building projects involving 'participants' and 'themes' of a process. Through induction, the data collections of experiments were analysed through a practice theoretical perspective based on analytical methods of 'A palette of zooming in' and mind maps visualised as boards for structuring the 'themes'. Multiple iterative processes occurred such as reorganising the 'themes' in the mind maps, comparisons of 'participants' of various experiments and addition of 'phases' to the original phases of a building project. The result of the five years of iterative processes of experiments was a Knotworking guideline including a scheme of themes.

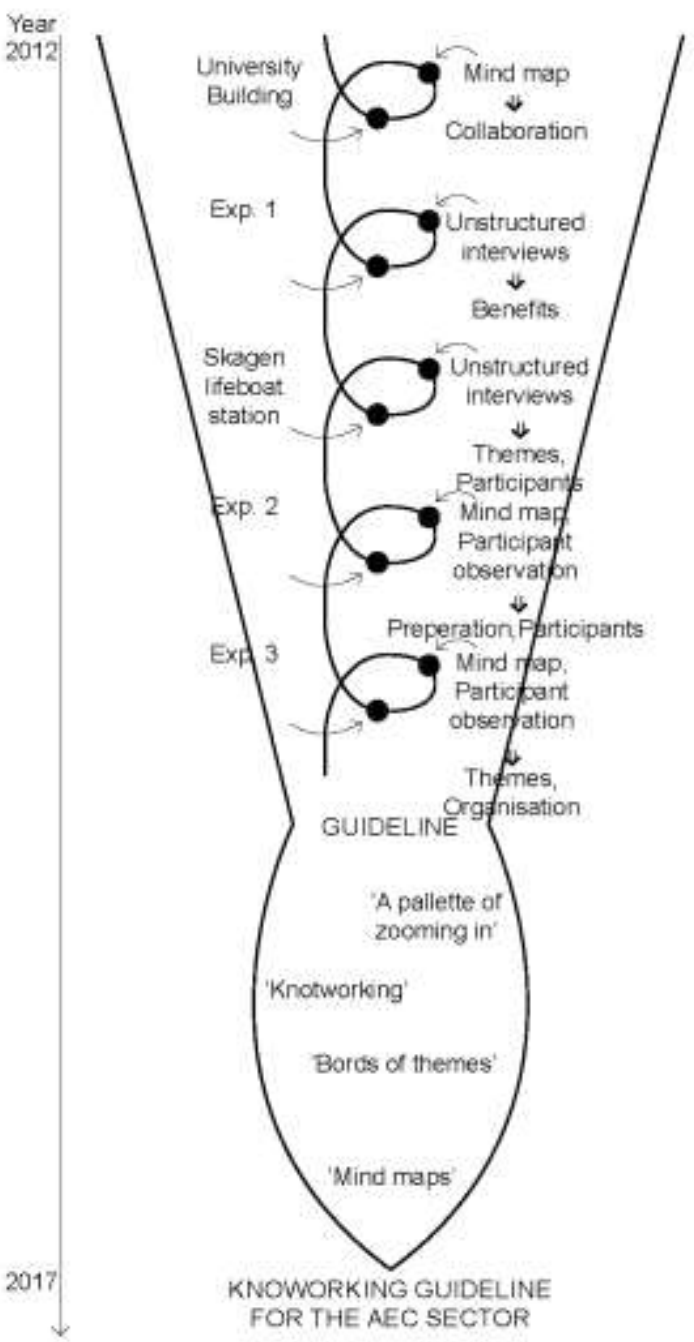

Fig. 8: Development of the results based on iterative processes concentrating the focus for further induction of both existing data of Knotworking and new data of Knotworking experiments. This results

in a Knotworking guideline for the AEC sector.

\section{RESULT}

Based on the objective of this research to develop a general guideline for building projects to bridge the gap between the participants, the following Knotworking Guideline for Building Projects is the result of this study. The Knotworking Guideline for Building Projects frames both the phases (further indicated by italic text), the participants (further indicated by underlined text) and the tasks (further indicated by bold text) of a general Knotworking session, and is visualised in Fig. 9. 


\begin{tabular}{|c|c|c|c|c|}
\hline \multicolumn{5}{|c|}{ KNOTWORKING GUIDELINE FOR BUILDING PROJECTS } \\
\hline & $\begin{array}{l}\text { END-USER } \\
\text { - Users }\end{array}$ & $\begin{array}{l}\text { OWNER } \\
\text { - paying }\end{array}$ & $\begin{array}{l}\text { EXECuTERs } \\
\text { - professionals }\end{array}$ & $\begin{array}{l}\text { Process-professionals } \\
\text { - external competences } \\
\text { supporting the work }\end{array}$ \\
\hline \multirow[t]{2}{*}{ 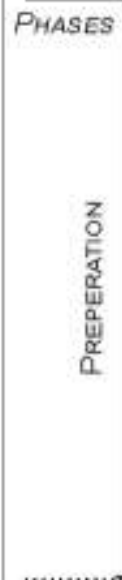 } & & $\begin{array}{l}\text { Contracts } \\
\text { Context } \\
\text { Pre-defined knots } \\
\text { Budget } \\
\text { Obligations } \\
\text { Building objects } \\
\text { Tools } \\
\text { Structure } \\
\text { Collaboration } \\
\text { Location and transport } \\
\text { Food } \\
\text { Observation } \\
\text { Setting-up }\end{array}$ & & $\begin{array}{l}\text { Understand budget } \\
\text { Read obligations } \\
\text { Building objects } \\
\text { Tools } \\
\text { Structure } \\
\text { Collaboration } \\
\text { Location and transport } \\
\text { Food } \\
\text { Observation } \\
\text { Setting-up }\end{array}$ \\
\hline & $\begin{array}{l}\text { Understand budget } \\
\text { Read obligations } \\
\text { Agreement on context }\end{array}$ & & $\begin{array}{l}\text { Understand budget } \\
\text { Read obligations }\end{array}$ & \\
\hline$\frac{a}{\frac{1}{a}}$ & Context & Context & $\begin{array}{l}\text { Pre-defined knots } \\
\text { Collaboration } \\
\text { Tools } \\
\text { Homework }\end{array}$ & $\begin{array}{l}\text { Presentation } \\
\text { Facilitate } \\
\text { Evaluations of the day } \\
\text { Homework }\end{array}$ \\
\hline 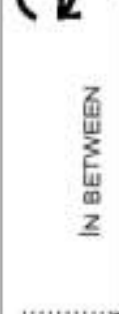 & $\begin{array}{l}\text { Homework } \\
\text { Execute internship }\end{array}$ & Homework & $\begin{array}{l}\text { Homework } \\
\text { Building objects } \\
\text { Internship at end-users }\end{array}$ & $\begin{array}{l}\text { Presentation } \\
\text { Tools } \\
\text { Structure } \\
\text { Location and transport } \\
\text { Food } \\
\text { Observation } \\
\text { Setting-up }\end{array}$ \\
\hline $\begin{array}{l}0 \\
\frac{10}{2} \\
\frac{x}{0} \\
0 \\
0 \\
\frac{1}{0} \\
\frac{1}{z} \\
x\end{array}$ & Inputs & $\begin{array}{l}\text { Setting-up } \\
\text { Inputs }\end{array}$ & $\begin{array}{l}\text { New knots } \\
\text { Collaboration } \\
\text { Designing } \\
\text { Homework }\end{array}$ & $\begin{array}{l}\text { Setting-up } \\
\text { Presentation } \\
\text { Pre-defined knots } \\
\text { Facilitate } \\
\text { Evaluations of the day } \\
\text { Homework }\end{array}$ \\
\hline 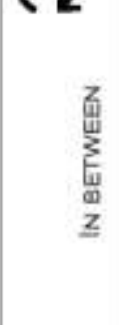 & $\begin{array}{l}\text { Comment on solutions } \\
\text { Homework } \\
\text { Confront colleagues }\end{array}$ & $\begin{array}{l}\text { Comment on solutions } \\
\text { Homework } \\
\text { Confront colleagues } \\
\text { Food } \\
\text { Location and transport } \\
\text { Setting-up }\end{array}$ & $\begin{array}{l}\text { Comment on solutions } \\
\text { Homework } \\
\text { Update data } \\
\text { Confront colleagues }\end{array}$ & $\begin{array}{l}\text { Update based on comments } \\
\text { Update based on evaluation } \\
\text { Invite new participants for } \\
\text { next session } \\
\text { Location and transport } \\
\text { Food } \\
\text { Observation } \\
\text { Presentation } \\
\text { Setting-up }\end{array}$ \\
\hline 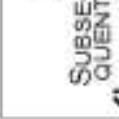 & & Tender & Tender & (Tender) \\
\hline
\end{tabular}

Fig. 9: A general Knotworking Guideline for

Building Projects indicating the phases, the participants and the tasks. The phases are situated vertically, the participants are situated horizontally, and the tasks are situated in-between these two axis. 


\begin{tabular}{|c|c|c|}
\hline & TASKs & BIREF DESCRIPTION AND SUGGESTIONS \\
\hline 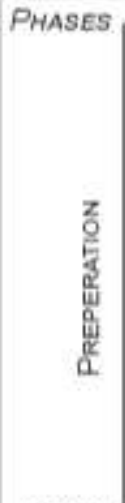 & $\begin{array}{l}\text { Contracts } \\
\text { Context } \\
\text { Pre-defined knots } \\
\text { Budget } \\
\text { Obligations } \\
\text { Building objects } \\
\text { Tools } \\
\text { Structure } \\
\text { Collaboration } \\
\text { Location and } \\
\text { transport } \\
\text { Food } \\
\text { Observation } \\
\text { Setting-up }\end{array}$ & $\begin{array}{l}\text { Content (objective of the project, division of roles, budgets, tasks etc) } \\
\text { Objective, content of the project and site information } \\
\text { Identify knots in relation to objective } \\
\text { Financial boundaries, Objects or activities related to the projects } \\
\text { Specific project (energy demands, legislation of the site, governmental obligations, etc.) } \\
\text { Criteria of objects of the project, 3D models of objects (furniture, material information etc.) } \\
\text { Tested and accessible (pen and paper, computer, decision schemes, VR-goggles, etc.) } \\
\text { Schedule (content, organisational diagram, etc.), information delivery (digital folders, etc) } \\
\text { Matching of expectation, availability of the participants, tuned in to Knotworking } \\
\text { One room to fit the participants and related activities, amounts of chairs and tables, ar- } \\
\text { rangement of transportation for equipment, internet and power available } \\
\text { Order correct amount of food and beverage } \\
\text { Knowledge to collect (comments on post-its, plan drawings, etc.) } \\
\text { Specific tools, physically rearrange the room, test digital tools multiple times }\end{array}$ \\
\hline 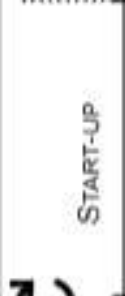 & $\begin{array}{l}\text { Presentation } \\
\text { Context } \\
\text { Pre-defined knots } \\
\text { Collaboration } \\
\text { Tools } \\
\text { Facilitate } \\
\text { Evaluation of day } \\
\text { Homework }\end{array}$ & $\begin{array}{l}\text { Information about days (context, objective, working method, digital tools, eto.) } \\
\text { Discuss the important aspects of the context } \\
\text { List of potential knots, agreement upon knots according to objective and potential outcon } \\
\text { Agree upon the working method within Knotworking. mactohing of expectation } \\
\text { Agree upon tools and edition of software } \\
\text { Ensure flat hierarchy and allow new ideas, keep the schedule } \\
\text { Collect data according to Observation in Preperation } \\
\text { Agree upon task for next session }\end{array}$ \\
\hline 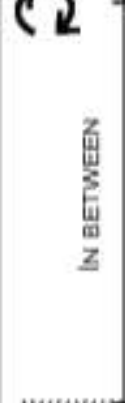 & $\begin{array}{l}\text { Homework } \\
\text { Presentation } \\
\text { Building objects } \\
\text { Tools } \\
\text { Structure } \\
\text { Location and } \\
\text { transport } \\
\text { Food } \\
\text { Observation } \\
\text { Setting-up } \\
\text { Internship }\end{array}$ & $\begin{array}{l}\text { Prepare task for next session } \\
\text { Implement observations from start-up session to the next session } \\
\text { Update objects and related activities (3D models, sample of materials, etc.) } \\
\text { Arrange the correct tools } \\
\text { Information delivery (digital folders, names of folders, etc) } \\
\text { One room to fit the participants and related activities, amounts of chairs and tables, } \\
\text { arrangement of transportation for equipment, internet and power available } \\
\text { Order correct amount of food and beverage } \\
\text { Accumulate and adapt observations } \\
\text { Specific tools, physically rearrange the room, test digital tools multiple times } \\
\text { Executers are a part of the existing working day of the end-users }\end{array}$ \\
\hline 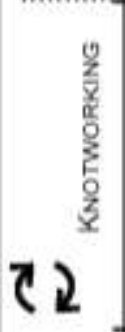 & $\begin{array}{l}\text { Setting up } \\
\text { Presentation } \\
\text { Inputs } \\
\text { New knots } \\
\text { Collaboration } \\
\text { Designing } \\
\text { Facilitate } \\
\text { Evaluations of day } \\
\text { Homework }\end{array}$ & $\begin{array}{l}\text { Final setting-up before the participants arrives } \\
\text { Information about days (context, objective, working method, digital tools, etc.) } \\
\text { Professional knowledge } \\
\text { Identification of new knots based on an iterative development of the project } \\
\text { Attitude of participants, structure for collaborattion, BygSoL meetings } \\
\text { Development of the project by tools and knots } \\
\text { Structure tasks, passive until conflicts arise, Knotworking meetings, keep schedule } \\
\text { Improve future Knotworking sessions, collect of information, informing external persons } \\
\text { Agree upon task for next session }\end{array}$ \\
\hline 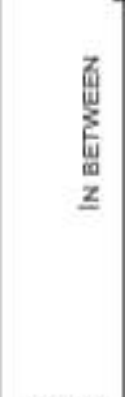 & $\begin{array}{l}\text { Comments } \\
\text { Update data } \\
\text { Confront colleague } \\
\text { Invite participants } \\
\text { for next session } \\
\text { Location and } \\
\text { transport } \\
\text { Food } \\
\text { Observation } \\
\text { Presentation } \\
\text { Setting-up }\end{array}$ & $\begin{array}{l}\text { Collect comments as a dynamic minute of the Knotworking session } \\
\text { Update drawings and economy } \\
\text { Gain further knowledge about specific tasiks of the project to ensure a high quality } \\
\text { Pre-defined knots indicates the professions involved } \\
\text { In some occasions, new specialist is required for inputs in the specific knot } \\
\text { One room to fit the participants and related activities, amounts of chairs and tables, ar- } \\
\text { rangement of transportation for equipment, internet and power available } \\
\text { Order correct amount of food and beverage } \\
\text { Accumulate and adapt observations } \\
\text { Implement observations from start-up session to the next session } \\
\text { Specific tools, physically rearrange the room, test digital tools multiple times }\end{array}$ \\
\hline & er & andle-in the project, upload everything required \\
\hline
\end{tabular}

Fig. 10: A brief description of the tasks in the Knotworking Guideline for Building Projects categorised into the various phases.

\subsection{Phases}

Based on data of the experiments, the guideline is divided into phases. The phases are vertically categorised into Preparation, Start-up, and 
a related In between phase, Knotworking, and a related In between phase, and lastly, a Subsequent phase.

\subsubsection{Preparation phase}

The Preparation phase covers the tasks to be completed prior to the gathering of the participants of the project. The Preparation phase is essential for the efficiency of the time of the participants, which was found through the experiment of the school project in Finland. In the study of the school project, which was the first Knotworking project in the construction industry [26], [31], four planning meetings were required for the concrete application of the general idea. Moreover, two general meetings were conducted with the client and end-users and then the design process in the actual Knotworking phase what initiated [26]. The aim of the meetings was to "plan the formation of Knotworking groups, the requirements for the initial data, timetables, working methods, the necessary tools, objectives to be set for the design work, assessment tools for the design solutions, and the collaboration with the client and the end users" [26, p. 3].

\subsubsection{Start-up phase}

Through that research, it was found, that an effort from all participants in the Start-up phase resembling the progression of the Knotworking session such as rapidly focus on the knots of the physical project instead of focusing on collaboration. Of this reason, the Start-up and related In between phase are emphasised in the guideline as being important and a new element compared to existing phases of a design process [9]. The Start-up phase is the first gathering of all participants. The aim of the gathering is a collective agreement on an object to reach a collective potential outcome. Through the first experiment of the school project and the third experiment of the Digital Days it was found, that the collective agreement upon an object and potential outcome enhanced the efficiency of the group to start designing at the Knotworking session.

The In between phase covers the individual homework of the participants and further reflection upon the decisions in the preparation of the project. The In between phase allocates time to individual reflection upon the solutions of the previous Start-up phase aiming to improve the project. Through the second experiment of the furnishing design, the benefits of the In between phase was observed by the cleaning staff being proud of their work and add comments on the work. Hereby, the colleagues of the cleaning staff additionally were included and gained ownership of the building. A similar procedure was conducted for the staff of the department resulting in a similar reaction of the staff members. Moreover, the benefits of the In between phase is the potential of working simultaneously on multiple projects at a time, which is a main difference between Knotworking and Big Room [26].

\subsubsection{Knotworking phase}

The content of the Knotworking phase is the actual designing to reach the object and potential outcome. Based on both the Preparation phase and the Start-up phase, the information is collected and understood when initiating the Knotworking phase. Similarly to the Start-up phase, all participants are involved in the Knotworking phase. The main tasks of the Knotworking phase are to design the product collaboratively with the inputs from all participants. The co-configuration of the collaboration is visualised through the engagement of the participants taking ownership of the project, which was found independently in the three experiments. Through iterative processes within the Knotworking phase, the knots are solved for the participants to agree upon the homework for the next Knotworking phase. Based on the three experiments, the length of the Knotworking phase varies according to the complexity of the project. However, a Knotworking phase of 1-3 days is preferable followed by an In between phase of 1-3 weeks before repeating the Knotworking phase with new inputs and knots. Similarly to the In between phase in relation to the Start-up phase, the In between in relation to the Knotworking phase benefits from the reflection of the project and further possibility of simultaneous working on other projects.

\subsubsection{Subsequent phase}

Lastly, the content of the Subsequent phase is to handle in the project to the Building owner and the End-users. The task could be Tendering according to the requirements of the building owner.

According to the complexity of the project, both the Start-up and related In between phases and the Knotworking and related In between phase is repeatable to the extent of reaching the objective of the specific phase.

\subsection{Participants}

Horizontally, the categories of the participants are promoted as the End-user, Owner, Executer and Process-professionals. The End-user covers the renters of the building such as the people working within the building, the maintenance staff, the landlord and the company of the employees occupying the building. The Building owner is the organisation owning the building, renting the building to the End-users and paying the Executors and Process-professionals for their work. The 
Executors are the building professionals conducting the design of the project by various skills caused by their professions such as architect, engineer and landscape architect. Lastly, the Process-professionals are external competencies supporting the work such as a facilitator and technical designers in charge of the BIM-models. The role of the facilitator and technical designers are new to the AEC sector and is enhanced by the Knotworking method. The purpose of the Process-professionals is for the participants to focus on their professions contrary on managing the process. As opposed to the traditional Silo-approach of the leaders of each profession talking to each other and having the technical designer in each Silo, the Knotworking method collects all participants to work collaboratively with the technical designers in the centre to feed them with information to implement in a digital model. The facilitator is situated in the outskirt of the project focusing on facilitating the process and not the project (Fig. 11).

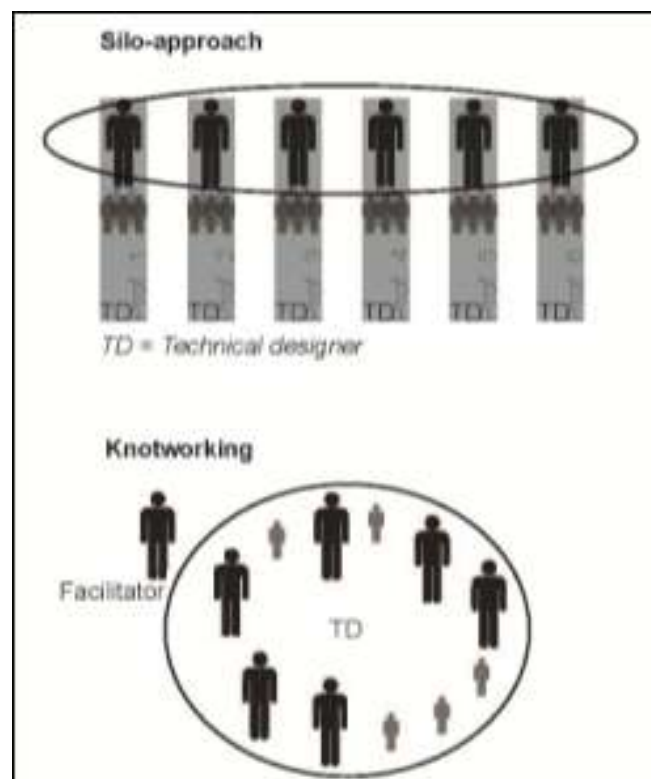

Fig. 11: Collaboration among the participants respectively according to the Silo-approach and Knotworking

\subsection{Tasks}

The content of the Knotworking Guideline for Building Projects is mediated as keywords indicating the tasks of each phase and participant. The Guideline consists of $\mathbf{2 7}$ tasks based on participant observations of experiment two and three. The tasks are broad caused by the fact that iterative processes occur within the Guideline, why this Guideline fits the majority of projects in the AEC sector. Contrary to the current phases of building projects identifying the aim of each phase [12], [51], the tasks of this Guideline organise the minor steps of the process. The predefined tasks allocate time for the participants to focus on their professions while designing a building causing professional discussions instead of discussions about how to collaborate, which was observed in the experiments. Significantly, this finding was expressed in the second experiment of the furnishing project, where the majority of the participants were unfamiliar with common design processes. However, the participants designed the spaces within a short time frame and without discussing how to organise the collaboration, caused by the Knotworking settings that the facilitator provided for the participants to follow. The specific tasks of the Guideline are briefly described in Fig. 10, where the task are divided into the separate phases.

\section{DISCUSSION}

\subsection{Collaboration}

The focus of this Guideline is collaboration caused by the complexity of the building industry. The traditional working method of the building industry is the Silo-approach separating the disciplines causing parallel work compared to collaboration [35]. This Knotworking Guideline is inappropriate for the Silo-approach caused by the open phases of the Guideline requiring collaboration among the participants. The consequence of applying the Knotworking concept to the Siloapproach is a lack of collaborative and completed ideas and knowledge unsuitable for information delivery. To beneficially adopt the Knotworking Guideline, collaboration is required and preferably embedded contractually such as Alliance projects addressing the sharing of risks and awards among the participants [52]. However, the implantation of the Knotworking Guideline in Alliance projects has to be studied further to draw solid conclusions on this.

Moreover, this Guideline emphasises coconfiguration involving the end-user early in the project and throughout the entire project with the executors involved at the same level as the endusers. The hierarchy is flat caused by the involvement of all participants based on the idea of horizontal learning creating knowledge [19]. Previous design processes involving end-users is often based on co-creation involving the end-users, but developing a product for the user to change. By co-creation, the executors do not anchor to the project, as is the case of co-configuration. The benefits of the participants anchoring to the project were emphasised in the experiments, where the participants collaboratively progressed to improve the project holistically. Of this reason, coconfiguration is suggested as beneficial for previous projects. 


\subsection{The recipe and the guideline}

Despite the few scientific papers embracing Knotworking AEC, a past master thesis visually characterises aspects of a Knotworking session in a recipe aiming to be implemented as a tool for design management [33]. Caused by the limitation of the publication of the recipe is in Finnish language and being a part of a master thesis, the recipe is not published worldwide. Of these reasons, it is challenging to use the recipe in practice in other countries than Finland. Moreover, the recipe was mostly determined sustainable buildings and the related tasks of the project.

The Guideline additionally indicates the tasks to fulfil, but at an overall level, while the recipe details the tasks. Based on the detailed level of the recipe and the general approach of the guideline, the two models are not contrasted why they in future research would benefit from complementing each other. However, the guideline derives a structure of how to conduct a Knotworking session, by indicating the various phases, the various participants and their involvement, and further the tasks of each phase and participant.

\subsection{Utilisation}

The experiments of this paper were conducted in the early design phase of a project. However, the idea has been scheduled to include the entire building project, which is anchored in this Guideline. Moreover, the Guideline is both applicable as the method of accomplishing a project, and applicable sporadically within existing methodologies covering the entire process. Some examples of existing methodologies are Integrated Project Delivery [35], Integrated Design Process [53], and Big Room [29]. The contribution of this Guideline to the AEC sector is a practical approach to utilisation of Knotworking AEC in practice.

\subsection{Other industries}

Even though this Guideline was developed for the AEC sector, the generalisation of the Guideline makes it applicable in multiple projectoriented processes involving various participants. Previously in Finland, Knotworking has been applied in both healthcare [54] and new partnerships of libraries [22], why it is argued that Knotworking as a method is applicable in multiple industries such as IT, manufacturing and project management in general. Despite the fact that the Guideline indicates tasks that are focusing on the AEC sector such as Building objects, these tasks are changeable to fit the specific industry implementing the Guideline. However, the Guideline has not yet been implemented in either the AEC sector or other industries, why further research is required to provide a verification of the actual benefits of the Guideline.

\section{CONCLUSION}

In this article, we presented a Knotworking Guideline for conducting a Knotworking session in practice, which can be applied by both researchers and practitioners within the AEC sector. The Guideline fills a gap in the Knotworking literature by providing specific steps for conducting a Knotworking session within a building design project of any scale. Based on existing literature on available studies of Knotworking and the accomplished experiments, three key findings are found.

The first key finding is the participants of the Knotworking session being participants of all represented organisations of the building project such as End-users, Building owners, Executers and Process-professionals. The second finding is the phases of the Knotworking session. The preparation phase contains the initial preparations involving the Building owner and the Process-professional. The Start-up phase contains all participants of the Knotworking session for them to comprehensively agree upon pre-defined knots and the final preparation prior to the designing of the product. The Start-up phase is related to an In-between phase continuing iteratively until collection of information is completed. The Knotworking phase contains the designing of the product. This phase involves all participants and is repeated in relation to an Inbetween phase until the product is accomplished. Lastly, a Subsequent phase contains the uploading of the project according to the requirements of the Building owner and the End-user. The third key finding is the tasks of each phase related to the specific participant. The tasks are developed based on the experiments to ensure progression and structure of the project. A brief description of the tasks is visible in a related scheme of the tasks. The related scheme elaborates the content of the tasks in the Guideline, which is designed separately to limit the amount of information in each figure.

This Guideline is the first of its kind guiding the participants through a Knotworking session by various tasks organised according to the phase of the Knotworking session. However, a previous study of a master student has developed a recipe which differs from this Guideline by going into details of the practical tasks of sustainable buildings. This Guideline is aimed at building projects of the AEC sector, in general, to be implemented either throughout the entire design process or as sporadical spots of the design process struggling with a challenging knot to solve. Further research is required to transform this Guideline into being accessible for the AEC sector and to implement in practice. 


\section{REFERENCES}

[1] F. Bougrain, M. Forman, and K. Haugbølle, Industrialisation in construction: Multiple actors, multiple collaborative strategies, in CIB 2010 World Congress proceeding, Standford, 2010.

[2] F. Chiocchio, D. Forgues, D. Paradis, and I. Iordanova, Teamwork in integrated design projects: Understanding the effects of trust, conflict, and collaboration on performance, Project Management Journal, 42(6), 2011, 78-91.

[3] E. Poirier, D. Forgues, and S. Staub-French, Collaboration through innovation: implications for expertise in the AEC sector, Construction Management and Economics, 34(11), 2016, 769-789.

[4] D. W. Chan and M. M. Kumaraswamy, A comparative study of causes of time overruns in Hong Kong construction projects, International Journal of Project Management, 15(1), 1997, 55-63.

[5] M. H. El. Reifi and S. Emmitt, Perceptions of lean design management, Architectural Engineering and Design Management, 9(3), 2013, 195-208.

[6] T. Subramani, P. T. Lishitha, and M. Kavitha, Time Overrun and Cost Effectiveness in the Construction Industry, Journal of Engineering Research and Applications, 4(5), 2014, 111-116.

[7] J. Zhuang, M. Hu, and F. Mousapour, ValueDriven Design Process: A Systematic Decision-Making Framework Considering Different Attribute Preferences From Multiple Stakeholders, Journal of Solare Energy Engineering, 139(2), 2017, 21001-121001-6.

[8] N. F. O. Evbuomwan and C. J. Anumba, An integrated framework for concurrent lifecycle design and construction, Advances in Engineering Software, 29(7-9), 1998, 587597.

[9] M. B. Rasmussen, Reasons for the delays of Public Buildings: Casestudy of Building for Department of Civil Engineering at Aalborg University 2011-2017, Aalborg University, Aalborg, 2017.

[10] W. Kymmell, Building Information Modeling: Planning and Managing Construction Projects with $4 D C A D$ and Simulations. McGraw-Hill Education, 2008.

[11] S. Kujala, User involvement: a review of the benefits and challenges, Behaviour of Information Technology, 22(1), 2003, 1-16.

[12] Bygningsstyrelsen, "Faser og Roller $i$ Byggeprojekter, ” København, 2013.

[13] E. B. N. Sanders, From user-centered to participatory design approaches, in Design and the Social Sciences, J. Franscara, Ed. (London: Taylor \& Francis Books Limited, 2002), 1-8.

[14] M. Steen, M. Manschot, and N. D. Koning, Benefits of Co-design in Service Design Projects, International Journal of Design, 5(2), 2011, 53-60.

[15] F. Farrelly and P. Quester, Investigating large-scale sponsorship relationships as comarketing alliances, Business Horizons, 48(1), 2005, 55-62.

[16] C. K. Prahalad and V. Ramaswamy, Cocreation experiences: The next practice in value creation, Journal of Interactive Marketing, 18(3), 2004, 5-14.

[17] E. Goh and M. Loosemore, The impacts of industrialization on construction subcontractors: a resource based view, Construction Management and Econonomics, 2016, 1-18.

[18] J. Virkkunen, Hybrid agency in coconfiguration work, Outlines. Critical Practice Studies, 8(1), 2006, 61-75.

[19] Y. Engeström, Enriching the Theory of Expansive Learning: Lessons From Journeys Toward Coconfiguration, Mind, Culture, and Activity, 14(1-2), 2007, 23-39.

[20] J. Gold and R. Thorpe, Collective CPD: Professional Learning in a Law Firm, in Handbook of Research on KnowledgeIntensive Organizations, IGI Global, 2009, 30-46.

[21] H. Kerosuo, BIM-based Collaboration Across Organizational and Disciplinary Boundaries Through Knotworking, Procedia Econonomics and Finance, 21, 2015, 201208.

[22] Y. Engeström, H. Kaatrakoski, P. Kaiponen, J. Lahikainen, A. Laitinen, H. Myllys, J. Rantavuori, and K. Sinikara, Knotworking in Academic Libraries: Two Case Studies from the University of Helsinki, LIBER Quarterly, 21(3/4), 2012, 387-405.

[23] Y. Engeström, From Teams to Knots: Activity-Theoretical Studies of Collaboration and Learning at Work (Learning in Doing: Social, Cognitive and Computational Perspectives), 3ed ed. (Cambridge University Press, 2008).

[24] H. Kerosuo, R. Miettinen, S. Paavola, and J. Korpela, Challenges of the expansive use of Building Information Modeling (BIM) in construction projects, Production, 25(2), 2015, 289-297.

[25] M. Cole, Cultural psychology: a once and future discipline (Cambridge: Belknap Press of Harvard University Press, 1996). 
[26] H. Kerosuo, T. Mäki, and J. Korpela, Knotworking - A novel BIM-based collaboration practice in building design projects, in Proceedings of the 5th International Conference on Construction Engineering and Project Management ICCEPM, 9-11, January 2013, Helsinki, 2013.

[27] H. Buhl, N. Hvid, and M. Andersen, Evalueringsrapport: Knotworking Redningsstation Skagen - Udviklingsprojekt for Forsvarets Bygnings og Etablissement Tjeneste, København, 2014.

[28] A. Khanzode, M. Fischer, and D. Reed, Benefits and lessons learned of implementing building virtual design and construction (VDC) technologies for coordination of mechanical, electrical, and plumbing (MEP) systems on a large healthcare project, ITcon, 13(Special Issue), 2008, 324-342.

[29] O. Alhava, E. Laine, and A. Kiviniemi, Intensive big room process for co-creating value in legacy construction projects, Journal of Information Technology in Construction, 20(Special Issue: ECPPM, 2014), 2015, 146-158.

[30] J. Korpela, Significance of Knotworking from the Client's Point of View, Procedia Economics and Finance, 21, 2015, 209-216.

[31] H. Kerosuo, T. Mäki, and J. Korpela, Knotworking and the visibilization of learning in building design, Journal of Workplace Learning, 27(2), 2015, 128-141.

[32] G. Scaratti, S. Ivaldi, and J. Frassy, "Networking and knotworking practices: work integration as situated social process," Jornal of Workplace Learning, 29(1) 2017, 2-23.

[33] R. Lassila, "Bim and Lean Construction method in construction project as builind design manamgent tools," Tampere University of Technology, 2016.

[34] S. Austin, A. Newton, J. Steele, and P. Waskett, Modelling and managing project complexity, International Journal of Project Managagement, 20(3), 2002, 191-198.

[35] AIA National and AIA California Council, Integrated Project Delivery: A Guide, (New York, 2007).

[36] S. Austin, A. Baldwin, B. Li, and P. Waskett, Analytical design planning technique (ADePT): a dependency structure matrix tool to schedule the building design process, Construction Managagement and Economics, 18(2), 2000, 173-182.

[37] B. Lawson, How Designers Think: The Design Process Demystified, 4th ed.
(Amsterdam: Architectrual Press, 2006).

[38] S. Rifbjerg, Hvad tonker arkitekten på?, 1st ed (København: Arkitektens Forlag, 2015).

[39] J. Korpela and H. Kerosuo, Working together in a knot: The simultaneity and pulsation of collaboration in an early phase of building design, in Procs 30th Annual ARCOM Conference, Portsmouth, 2014, 865-874.

[40] E. F. Pedersen, The Construction Industry takes up the Gauntlet, in CIB W096 Architectural Management, Copenhagen, 2005, 397-406.

[41] A. Buch, The Legacy of Practice Theory, Aalborg University, København, 2014.

[42] T. Hargreaves, Practiceing behaviour change: Applying social practice theory to pro-environmental behaviour change, Journal of Consumer and Culture, 11(1), 2011, 79-99.

[43] J. Rouse, Practice Theory, in D. M. Gabbay, P. Thangard, and J. Woods (Eds.) Handbook of the Philosophy of Science, 15, (Elsevier BV, 2006) 499-540.

[44] T. R. Schatzki, Practice Mind-ed Orders, in T. R. Schatzki, K. D. Knorr-Cetina, and E. von Savigny (Eds.), The practice turn in contemporary theory (London: Routledge, 2001) 42-55.

[45] D. Nicolini, Practice Theory, Work, and Organization: An Introduction, 1st ed. (Oxford: Oxford University Press, 2013).

[46] D. Nicolini, Mattering workshop with Professor Davide Nicolini: Zooming in and zooming out: Phenomena, practice theory and nexus analysis, 2015.

[47] A. Warde, Some problems in applying theories of practice to consumption, 2014.

[48] H. R. Bernard and G. W. Ryan, Analyzing qualitative data: systematic approaches (London: SAGE, 2010).

[49] M. L. Small, Lost in Translation: How Not to Make Qualitative Research More Scientific, Report from Workshop on Interdisciplinary Standards for Systematic Qualitative Research, (Washington, DC, 2005) 1-8.

[50] M. Rasmussen, R. L. Jensen, and A. M. Fisker, Knotworking In An Interior Décor Process, The University of Huddersfield Press, 2016.

[51] Foreningen af Rådgivende Ingeniører and Danske Arkitekt Virksomheder, Ydelsesbeskrivelser Byggeri og Planlagning 2012, 1st ed. København: HJ Gradisk, 2012.

[52] J. Ross, Introduction to Project Alliancing (on engineering and construction projects), Introduction to Project Alliancing, Sydney, 
2003.

[53] H. T. R. Hansen and M.-A. Knudstrup, "The Integrated Design Process (IDP) - a more holistic approach to sustainable architecture, The 2005 World Sustainable Building Conference, 2005, 894-901.

[54] Y. Engeström, Activity theory as a framework for analyzing and redesigning work., Ergonomics, 43(7), 2000, 960-974. 